\title{
Evaluating Sport Sponsorship Model among Soccer Fans in Iran
}

\author{
Kamran Eshghi ${ }^{1}$, Reza Mohammad Kazemi ${ }^{2}$, Hashem Aghazadeh $^{3}$ \& Apena Hedayatnia ${ }^{3}$ \\ ${ }^{1}$ DeGroote School of Business, McMaster University, Hamilton, Canada \\ ${ }^{2}$ Faculty of Entrepreneurship, University of Tehran, Tehran, Iran \\ ${ }^{3}$ Faculty of Management, University of Tehran, Tehran, Iran
}

Correspondence: Kamran Eshghi, DeGroote School of Business, McMaster University, Hamilton, ON, L8P 3H3, Canada. Tel: 1-647-718-3671. E-mail: eshghik@mcmaster.ca

Received: May 12, 2013

doi: $10.5430 /$ bmr.v2n2p37
Accepted: June 3, 2013

Online Published: June 4, 2013

URL: http://dx.doi.org/10.5430/bmr.v2n2p37

\begin{abstract}
In this paper, we investigate the effectiveness of sport sponsorship among soccer fans in Iran. The effects of sport sponsorship through team attachment were evaluated on brand awareness, corporate image, purchase intent and loyalty. Confirmatory factor analysis was conducted to examine goodness of fit of the measurement model for the research constructs, the factor structures and dimensionalities of constructs. Construct validity and reliability of items were also examined. Then, structural equation modeling was conducted to check the hypothesized relationships among constructs. The results show that team attachment is positively related to corporate image, purchase intent and loyalty, but it is not positively related to brand awareness.
\end{abstract}

Keywords: Sport sponsorship, Brand awareness, Corporate image, Purchase intent, Loyalty, Team attachment

\section{Introduction}

Sponsorship has become a progressively significant element of a firm's marketing mix, with many corporations actively pursuing sponsorship as a communication strategy in an attempt to evade the clutter associated with more traditional marketing communications (Meenaghan, 1996). Therefore, companies are allocating significant amounts of money to sponsorship (IEG, 2013). In the past, the communication mix available for companies consisted of advertising, sales promotion, and public relations. However, sponsorship is now an additional tool available for companies to communicate with their target audiences (Vignali, 1997). Many companies make investments to sponsor the famous and popular sports club especially, soccer clubs. Sponsorship spending has increased considerably around the world. There can be no doubt that global expenditure on sponsorships and associated activities constitutes an essential proportion of corporate communication budget (Crompton, 1994). Consumers mostly regard advertising as a self-interested marketing activity and believe that the advertising company of brand cannot increase its interest in the company and brand (Simmons \& Becker-Olsen, 2006). Therefore, sport sponsorship has many advantages as an element of sport marketing mix and it is more effective than regular advertising. One way to provide sufficient money for sport activities, especially championship activities, is the use of sponsorship of private enterprises and companies (Smith, 2008; Meenaghan, 2001). Conventionally, sponsorship is used most widely in the sport industry (Olson \& Thjomoe, 2009). Approximately, sport sector attracts 54-65\% of spending on sponsorship (IEG, 2013). In this environment, sports sponsorship has become an influential marketing tool because it is flexible and it reaches a broad audience (Ko, Kim, Claussen \& Kim, 2008).

Sport in Iran is similar to other parts of the world. In 2010, total global sponsorship spending reached $\$ 46.3$ billion, and it reached $\$ 48.7$ billion in 2011 (IEG, 2011). According to predictions, sponsorship's growth rate will be higher than advertising and sales promotion's growth rate. Among different kinds of sponsorship (sports, entertainment, cultural affairs, arts, etc.), sport sponsorship has the greatest share of $\$ 12.38$ billion (68\%) in 2011 (IEG, 2011). Moreover, among various sport events, soccer attracted most of sport sponsorship budget to itself because it is the most popular sport around the globe (Deloitte, 2011). According to Football Money League many European soccer clubs' income originated from sponsorship (Deloitte, 2011). In 2009/10 season, Real Madrid's revenue was €438.6 million (Deloitte, 2011). Revenue from commercial activities of this soccer club was $€ 150.8$ million ( $34 \%$ of total 
revenue). Sponsorship of commercial firms constitutes the most significant part of this revenue. Real Madrid's shirt front deal with Bwin runs until 2012/13 and reportedly generates between $€ 15$ million and $€ 20$ million per season. Adidas will be Real Madrid's kit sponsor until 2011/12. Other partnerships, including Audi and Coca-Cola also contributed to commercial income of Real Madrid in 2009/10 (Deloitte, 2011). Other soccer clubs in Europe and other continents earn a significant part of their income from sponsorship. Asian soccer clubs are progressing toward sponsorship to cover part of their expenses by employing sponsorship.

The 2001/02 season was the first professional soccer league in Iran. Up until 2011, the league had no private sponsorship and a large majority of the teams participating in the league belonged to public sector industries, government subsidies and companies, but teams covered part of their expenses through sponsorship. Starting from the 2011/12 season, the league is sponsored by MTN Irancell (The second telecommunication provider in Iran) for approximately \$2.55 million for one year (Persian Gulf professional Football League, 2011). Many international and countrywide corporations that do business in Iran have a tendency to invest in sport sponsorship as a promotional tool. During the last decade, sponsorship expenditure in Iran has increased at a high rate and many companies are seeking sponsoring teams, which are popular and have a lot of fans. Mostly, sport clubs, which have reputable brands with history and tradition augmented by the support that reaches beyond domestic markets, are the most successful in driving commercial revenues. In Iran, there are two popular soccer clubs which are among top Asian soccer clubs. They are also among the oldest soccer clubs in Iran and have several million fans. Consequently, they attract many international and domestic companies. For example, Marry Brown, Malaysian chain fast food restaurant, signed a $\$ 1$ million contract with the Persepolis soccer team for the 2008/09 season. In addition, Iran Furniture Market and Iran Mobile Market became the sponsors of the Esteghlal soccer team for 2008/09.

Sponsoring soccer teams, companies seek a return on investment, but many of these companies do not know how to examine the effectiveness of their marketing activities or which method to use for measuring the effects of sponsorship. Sport sponsorship allows the sponsors to communicate more directly and closely with their target market, but the effects of such marketing activities on target markets are unidentified. It is important for both sponsor and sponsee to measure sponsorship effectiveness. There does not exist enough research about measuring the effectiveness of sport sponsorship in Iran (Izadi, 2004). The effects of sport sponsorship on brand awareness and purchase intent are not the subject of any research in Iran. In spite of the increasing importance of sponsorship as a marketing communication tool, little is known about how sport fans process this information in their brand and image assessment. Although many researchers have sought to provide theoretical explanations about the fans' assessment of sponsorship and its effects on brand awareness, corporate image and other fans' metrics, little research has focused on sponsorship effectiveness in Iran. The present study evaluates the effectiveness of sports sponsorship among soccer fans (Persepolis and Esteghlal teams) in Iran.

\section{Literature Review}

\subsection{Literature Review}

In recent times, many corporations have found that sport sponsorship is a valuable strategy to enter new markets. Companies used sponsorship to create corporate image and position their brands in the mind of consumers more than ever (Quester \& Farrelly, 1998). Using sport sponsorship, companies can reach many audiences. Especially audiences that corporation cannot reach by other communication tools such as advertising. It is appropriate to define sponsorship and sports sponsorship before talking about objectives and outcomes of sponsorship.

Different authors suggest different definitions of sponsorship depending on their view of the topic. Here, we pointed to two definitions that help us understand the meaning of sponsorship. Sponsor is a person or organization that pays the expenses of an event or its broadcasting in return for advertising activities. According to Meenaghan's definition, "sponsorship is an investment, in cash or in kind, in any activity, in return for access to the exploitable commercial potential associated with that activity" (Meenaghan, 1983). Another researcher, Pope (1998), describes sponsorship as "the provision of resources (e.g., money, people, equipment) by an organization (the sponsor) directly to an individual, authority or body (the sponsee), to enable the latter to pursue some activity in return for benefits contemplated in terms of the sponsor's promotion strategy, and which can be expressed in terms of corporate, marketing or media objectives".

As we can see the definitions, they are somehow different and the separating point is the objective of sponsorship. Bennett (1999) stated a few objectives for sponsorship in his research. Other researchers added different objectives to Bennett's list and the most important ones are: sales increase, creating corporate public image, reaching small and distinguished audience, attraction and retention of competent employees and multiple objective. Although many companies pursue different objectives for their sponsorship and many researchers focus on these objectives, 
Cornwell and Maignan (1998) proposed five basic research areas about sponsorship: (1) nature of sponsorship, (2) managerial aspects of sponsorship, (3) measurement of sponsorship effects, (4) strategic use of sponsorship, (5) legal and ethical considerations in sponsorship. Among these research streams, measurement of sponsorship effects has attracted a lot of attention by academicians and researchers. Generally, scholars have examined the effects of sports sponsorship in two ways (Kim, 2010). Some have used a consumer psychology approach which integrates effect of sports sponsorship in terms of consumers' awareness, recognition, and behavioral intentions. Others focused on grasping the potential contribution of sports sponsorship to positive or negative changes in stock price (Kim, 2010). In this study, we focus on consumer psychology approach. Therefore, we present the literature review regarding consumer psychology perspective.

Sponsorship effectiveness evaluation has been identified as the most important challenge that researchers and managers facing in sponsorship field (Crompton, 2004). The issue of sport sponsorship effectiveness has been widely researched in different countries. The sponsorship literature supports the need for improved frameworks and models for more advanced evaluation of sponsorship (O'Reilly \& Madill, 2009). Among the early research evaluating sport sponsorship effectiveness, many studies focused on brand awareness of sponsors in the minds of consumers. Müller (1983) examined the effects of sport advertising (that includes sport sponsorship) on awareness particularly brand recall by considering age, gender and sport interests of the audience. In a study in South Africa that was conducted by Abratt and Globler (1989), who used survey of 28 sponsors, concluded that sports sponsorships could provide economic exposure or associate a brand or company with a specific event, providing high visibility, especially if the event has nationwide or global appeal. The focus of research was on awareness level of sponsorship. In another study in France, Couty (1994) evaluated sport sponsorship from awareness perspective among tennis fans. In another study, Gwinner (1994) examined tangibles and intangibles factors in sponsorship decision making process. He evaluated effects of sponsorship on brand image and on product involvement. Nicholls, Roslow and Laskey (1994) investigated 267 spectators and nine major sponsors at a golf tournament in USA. They measured sponsorship effectiveness in terms of consumer preference for the brand. Findings show that a steady progression in consumer preference is observed for only one product category (soft-drink).

In a study in Denmark that was conducted by Hansen and Scotwin (1995), sponsorship effectiveness was measured in terms of recall, recognition, and image changes. They analyzed 220 students and five companies. They concluded that sponsorship is more well-organized and efficient when it is explicit and when it is used in combination with advertising. D'Astous and Bitz (1995) conducted empirical tests on the implications of congruity theory for the formation of consumer attitudes. They established that the link between the sponsor and the event creates a non-linear effect on sponsor image. Easton and Mackie (1998) examined awareness level of sport sponsorship in Euro 1996. McDaniel (1999) examined sponsorship effectiveness from consumer behavior view that consumers possess images that influence their reactions to advertising leveraging sport sponsorships. Meenaghan and Shipley (1999) examined media effect on commercial sponsorship. In their view, messages and media are not separable in sponsorship. The results of their study showed that company's goodwill, which is generated amongst consumers as a result of sponsorship involvement, fluctuates by kind of sponsorship.

Speed and Thompson (2000) examined the effects of consumers' attitudes about a sport event in Australia, their perceptions of sponsor-event fit, and their attitudes about the sponsor on a multidimensional measure of sponsorship response. The findings showed that important factors in generating a favourable response from sponsorship include sponsor-event fit, perceived sincerity of the sponsor, perceived ubiquity of the sponsor, and attitude toward the sponsor. In a study by Lardinoit and Derbaix (2001), effects of field sponsorship on aided and unaided brand recall among respondents were measured, and findings were discussed with reference to respondents' level of involvement with a sport. In another study, Bennett, Henson, and Zhang (2002) conducted research in USA regarding recognition towards action sport sponsorship. They suggested that members of generation $\mathrm{Y}$ are interested in action sports and the sponsors of the events.

Koo, Quarterman and Flynn (2006) used the 2003 College Bowl Championship Series as a sample event, and they evaluated the effect of perceived brand/sport event image fit on consumers' responses, the effects of consumers' cognitive and affective responses on purchase intent. In a study by Miloch and Lambert (2006), consumer awareness of sponsorship at a grass-roots and niche sport event was assessed through an examination of recall and recognition rates and purchase intentions. Mason and Cochetel (2006) examined brand awareness among consumers after a change in sponsor and audience perceptions about the sponsors and the event before and after the change. The findings of the study showed that the original sponsor maintained high awareness levels with the audience, particularly awareness of the previously sponsored event, thus supporting the proposition that long-term sponsorship supports long-term brand awareness. 
In another study, Harvey, Gary and Despain (2006) measured the effectiveness of sponsorship through internet. The findings showed that sponsorship operates through different cognitive processes than those used by old-fashioned advertising. Benekas (2007) evaluated sport sponsorship effectiveness among soccer fans in Greece. The results suggested that respondents' awareness levels were high only for the sponsor of their favorite team and the one of their rival. However, respondents showed that their image perceptions and purchase intentions were mixed towards the sponsor of their favorite team and disappointingly negative for the rival sponsor. Koo et al. (2008) in a study that is conducted in Korea evaluated theoretical connections between main variables of sponsorship effectiveness that include brand awareness, corporate image and purchase intent. Involvement in the sport of soccer was also added to other variables as a main consumer variable. Results showed that purchase intentions were more likely to happen when consumers have a positive image of the sponsors and have a high-level of sports involvement, and that consumers' sports involvement positively affected sponsor awareness, corporate image and purchase intention. Dees, Bennett and Villegas (2008) evaluated sponsorship activities at elite intercollegiate football events. They analyzed the effects of the constructs of attitude toward the sponsor, goodwill, and fan involvement on consumer purchase intentions. Their results showed that goodwill have the most impact on consumers' intentions to support the corporate sponsors via purchasing behaviors. In another study, Schlesinger and Gungerich (2011) examined the effect of fan identification with a sports club on consumers' attitudes toward the sponsor and consumers' purchase intentions on a Swiss Ice Hockey club. The results supported the assumption that highly identified fans are more likely to exhibit several positive effectiveness related to sport sponsorship than low-invloved fans. Finally, Meenaghan and O'Sullivan (2013) posit a critique of current practice in the evaluation of sponsorship effectiveness and examine inherent problems arising from the use of the two important metrics that are currently used by the practitioner to measure sponsorship effectiveness, "Media Exposure" and "Sponsorship Awareness."

As we can observe from the literature review, a few studies have been conducted in the context of sport sponsorship in Iran compared to outside of Iran. Iran soccer league becomes professional, and Iran Pro league started a few years ago. Some of the sport sponsorship studies which were conducted in Iran are listed here.

Izadi (2004) examined the factors that have effect on corporate sponsors of Iran's professional league. The results indicated that soccer sponsorship in Iran could partly assist the firm's access to the target markets and competitive advantages against the competitors. Mohammad Kazemi (2007) described the marketing mix elements in the soccer industry of Iran compared to two Asian countries (South Korea \& Japan). In this research, sport sponsorship as one of the sub components of four elements of the marketing mix in the soccer industry was measured and compared to South Korea and Japan. In another study, Faed (2007) focused on how and why companies in the electronic industry used sports sponsorship. He also described the varieties of objectives when involving in sports sponsorship. Only few studies have been conducted about sport sponsorship in Iran. In this study, we will evaluate sport sponsorship effectiveness among soccer fans in Iran.

\subsection{Conceptual model and hypotheses}

While many scholars have tried to measure sponsorship effectiveness, there has been no consistency with respect to the predictor variables and outcomes being measured (Cornwell \& Maignan, 1998). Moreover, evaluating sponsorship effectiveness based on single variables may not be sufficient due to the complex nature of the process of developing perceptions about sponsorship. Evaluation of the sponsorship is one of the most controversial and definitely the most difficult component of sponsorship. However, the high numbers of objectives pursued by companies and the use of other promotional tools for leveraging purposes make sponsorship evaluation a complicated task (Berrett, 1993; Crompton, 2004; Meenaghan, 1983). This may explain the lack of a comprehensive theoretical model in sponsorship evaluation. We reviewed and evaluated all related variables to sport sponsorship effectiveness from various studies, which were conducted across the globe (Benekas, 2007; Couty, 1994; Gwinner, 1994; Hansen \& Scotwin, 1995; Koo et al, 2006; Lardinoit and Derbaix, 2001; Miloch \& Lambert, 2006; Muller, 1983; Nicholls, et al, 1994; Quester \& Farrelly, 1998; Speed \& Thompson, 2000; Yong Jae et al.,2008) and we identified the four variables as the most important ones: brand awareness, corporate image, purchase intent, and loyalty. In the present study, we evaluate the effects of sport sponsorship through team attachment on brand awareness, sponsor image, purchase intention, and loyalty.

We inserted new variable into our model: team attachment. In sport settings, the construct of team attachment represents a fan's interest in pursuing soccer matches and we can define it as an unobservable state of interest toward a soccer club. Team attachment refers to the psychological connection of fan to a sports team (Tsiotsou and Alexandris, 2009). Fans with a high-level of team attachment were found to attend more matches compared to those with a low attachment level (Wann and Branscombe, 1993). Frequency of watching soccer matches (T1), places of 
the seat in stadium (T2) and using sport kits of the favorite team (T3) help us measure this latent variable. The more the fans attend a stadium to watch their favorite team matches, the more they are involved in soccer activity. We evaluate the relationship of this variable with other variables of the study.

Brand Awareness - brand awareness measures the accessibility of the brand in memory, and it is the most widely used sponsorship outcome (Cornwell et al., 2001; Koo et al., 2006; Mason and Cochetel, 2006; Miloch and Lambert, 2006). Brand awareness can be measured through its two sub components: brand recall or brand recognition (Keller, 1993). Brand recall reflects the ability of consumers to retrieve the brand from memory when given the product category, the needs fulfilled by a category, or some other type of probe as a cue. Brand recognition reflects the ability of consumers to confirm prior exposure to the brand. According to Aaker, brand awareness has three levels which, two of them are introduced earlier: brand recall, brand recognition and top of the mind brand (Aaker, 1991). In order to measure the latent variable (brand awareness), we have to measure observed variables. The brand awareness construct consists of two items: B1 (brand recall) and B2 (brand recognition). The following hypothesis is proposed regarding brand awareness.

H1. Team attachment is positively related to brand awareness.

Corporate Image - corporate image is a mental image that comes to mind when we think about the company (sponsor). Corporate image is "the total impression that the entity makes on the minds of individuals" (Dichter, 1985) and "the image associated with the name of an organization" (Gatewood et al., 1993). The research regarding corporate image is limited in comparison to other variables (Hansen \& Scotwin, 1995; Ja Valgi et al., 1994; Pope and Voges, 1999; Rajaretnam, 1994; Sandler \& Shani, 1989; Turco, 1995). Since we cannot measure corporate image directly, we have to measure observed variables. The corporate image construct can be categorized into three distinct items: $\mathrm{C} 1$ (positive attitude), $\mathrm{C} 2$ (perception improvement) and $\mathrm{C} 3$ (product/service liking). This gives rise to the following hypothesis.

H2. Team attachment is positively related to corporate image.

Purchase Intent - Purchase intention is one of the most widely used sponsorship outcomes (Alexandris et al., 2007; Gwinner \& Swanson, 2003; Harvey, 2001). It is often difficult to precisely measure sales that have originated directly from sponsorship activity. One solution to this problem is to find out if consumers intend or plan to purchase the sponsor's product. Purchase intentions are, therefore, a proxy for actual sales, in that they represent a substitute, or a stand-in measure. Purchase intentions can also be considered a proxy for actual behavior that is for buying and consuming a product. It is obvious, however that planned behavior and actual behavior can be quite different (Smith, 2008). In another study, Harvey et al. (2006) reported that sponsorship may change consumers' responses towards a specific sponsor, and may facilitate the development of positive attitudes towards the sponsor, which then leads to increased consumer willingness to buy the sponsor's products. In order to measure purchase intent, we have to measure its observed variables. Purchase intent consists of three observed variables: P1 (considering buy in future), P2 (will try to buy in the future) and P3 (will purchase in the future). We proffer the following hypothesis to evaluate the effects of team attachment on purchase intent.

H3. Team attachment is positively related to purchase intent.

Customer Loyalty - loyalty is defined as "repeat purchase with a favorable attitude" (Jensen and Hansen, 2006, p. 442). Customer loyalty is the measure of feelings and attitudes that leads to repurchase of products and services from the previous company. Customer loyalty is an essential criterion to measure the success and profitableness of company. The foundations of the most successful marketing plans are customer loyalty programs. Customer loyalty is rarely evaluated as sponsorship effectiveness construct. Customer loyalty cannot be evaluated directly since it is a latent variable. Customer loyalty consists of L1 (recommendation of company products/services), L2 (regular use) and L3 (repurchase). The following hypothesis is proposed according to the literature review. It is important to note that all variable are measured according to sport sponsorship activity and fans perspective of sport sponsorship effects.

H4. Team attachment is positively related to loyalty.

According to four main variables and their observed variables, the conceptual model is formulated as figure 1 . 


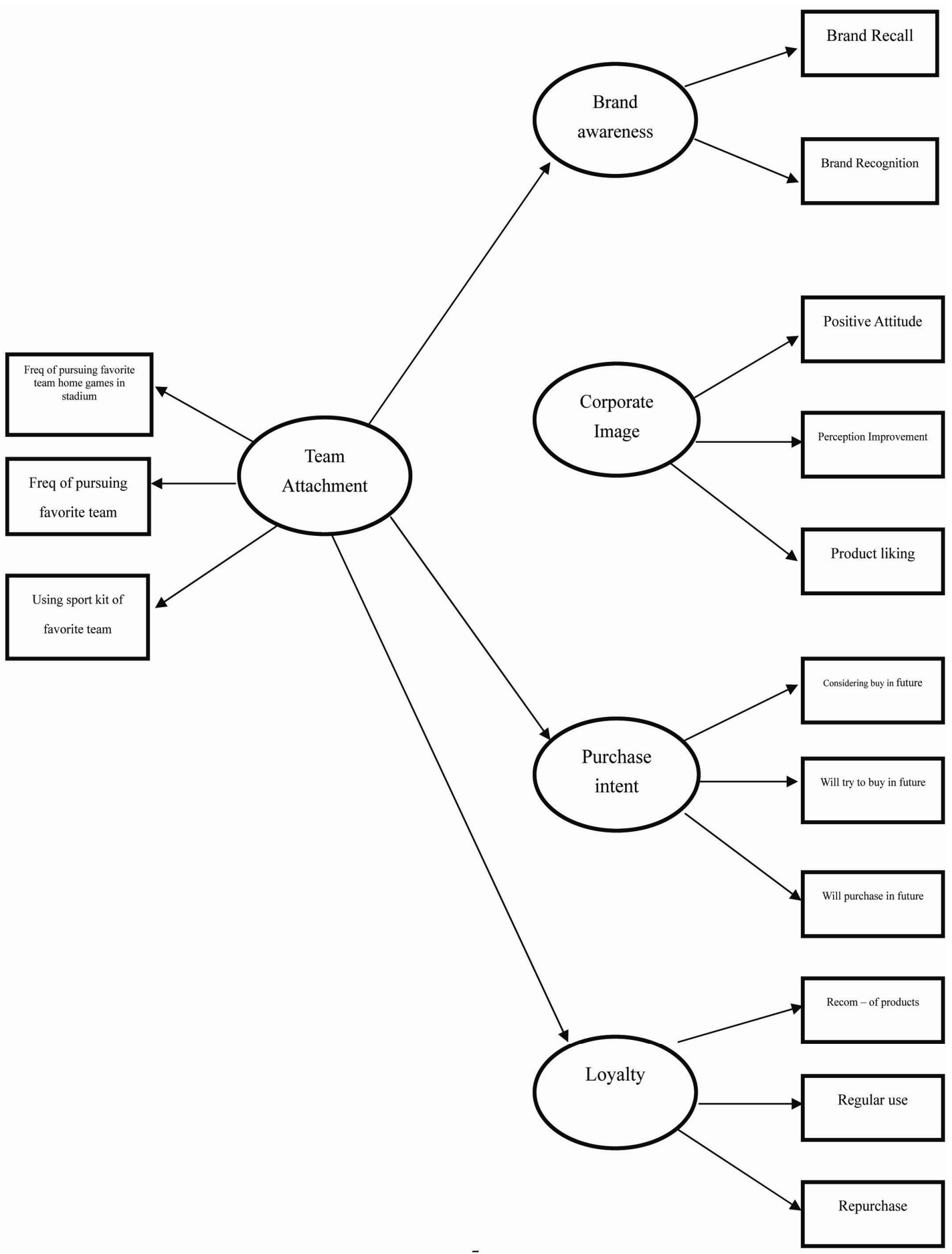

Figure 1. Sport sponsorship constructs 


\section{Method}

The focus of this study is to evaluate the relationships among sport sponsorship effectiveness variables from fans' perspective. In order to test the hypotheses, we used a questionnaire to acquire the views of soccer fans. A structured questionnaire was developed for the survey. The questionnaire consisted of two sections. To get information about personal background of the respondents, questions regarding their gender, age, education level and marital status were included in the first part of the questionnaire. In the second part of questionnaire, respondents were asked to rate the relative importance of five variables, using a five-point Likert type importance scale ranging from " Strongly agree " to "Strongly disagree ". This section included 14 questions and measured brand awareness, corporate image, purchase intentions and loyalty.

The data were analyzed in a two stage process. First, the measurement model was evaluated via confirmatory factor analysis to assess the reliability and unidimensionality of the scales used in the study. Once we were satisfied with the measurement model, a structural model was estimated using the LISREL's path analysis method. Using these methods, the overall model fit and the hypothesized relationships are assessed.

\subsection{Participant (Subject) Characteristics}

The statistical population of this study included Persepolis and Esteghlal fans who were members of fan clubs and social websites such as Yahoo Groups. Finally, 450 Persepolis and Esteghlal fans are randomly selected as statistical sample and the questionnaires were sent electronically to them. After collecting the questionnaires, we exclude some questionnaires because of being incomplete and lack of cooperation of fans which in final 384 complete questionnaires, 192 Persepolis fans and 192 Esteghlal fans represented the samples in this study.

\subsection{Measurement model}

The entire measurement model was subjected to confirmatory factor analysis. Content validity and convergent validity method were used to test the validity of items. Content validity (logical validity) refers to the extent to which a measure represents all facets of a given construct. After getting the opinions of several experts (25) in marketing and sports education, we conducted validity test. It is essentially a method for gauging agreement among raters or judges regarding how essential an item is. All the experts on the judging panel responded to the following question for each item: "Is the knowledge measured by this item 'essential,' 'useful, but not essential,' or 'not necessary' to the performance of the construct?" According to Lawshe (1975), if more than half of the experts indicate that an item is essential, there is some evident of content validity. Greater levels of content validity exist as larger numbers of experts agree that a particular item is essential. Using the following formula, we calculated the content validity ratio.

$$
\mathrm{CVR}=(\mathrm{ne}-\mathrm{N} / 2) /(\mathrm{N} / 2)
$$

Where CVR $=$ content validity ratio,

ne $=$ Number of experts indicating "essential",

$\mathrm{N}=$ Total number of experts

This formula yields values which range from +1 to -1 . If we obtained positive values, it indicates that at least half of the experts rated the item as essential. The mean CVR across items may be used as an indicator of overall test content validity. The $\mathrm{N}$ was 25 and "ne" was variable for different items. The mean CVR was .745 which indicates high content validity of questionnaires. Table 1 shows content validity of each item distinctively.

Table 1. Content validity ratios

\begin{tabular}{lcc}
\hline Variables & $n_{e}$ & $C V R$ \\
\hline Brand Awareness & & \\
Brand Recall & 23 & .84 \\
Brand Recognition & 22 & .76 \\
Corporate Image & & \\
C1 (positive attitude) & 21 & .68 \\
C2 (perception improvement) & 21 & .68 \\
C3 (product/service liking) & 21 & .68 \\
Purchase Intentions & & \\
P1 (considering buy in future) & & \\
P2 (will try to buy in future) & 24 & .92 \\
P3 (will purchase in future) & 22 & .76 \\
& 21 & .68 \\
\hline
\end{tabular}




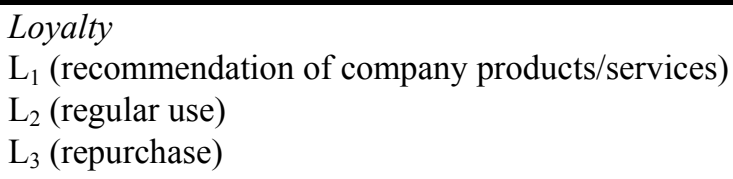

Team Attachment

$\mathrm{T}_{1}$ (frequency of pursuing favourite team home games in stadium)

$\mathrm{T}_{2}$ (frequency of pursuing favourite team away games in stadium) $\mathrm{T}_{3}$ (using sport kit of favourite team)

$\begin{array}{ll}23 & .84 \\ 21 & .68 \\ 21 & .68 \\ & .68 \\ 21 & .68 \\ 22 & .76 \\ 23 & .84\end{array}$

There are other measures that are useful for establishing validity such as Average Variance Extracted (AVE). AVE scores should be greater than .5 (AVE > 0.5) (Hair, Black, Babin \& Anderson, 2010). If there are convergent validity issues, then variables do not correlate well with each other within their parent factor; i.e., the latent factor is not well explained by its observed variables. If there are discriminant validity issues, then variables correlate more highly with variables outside their parent factor than with the variables within their parent factor; i.e., the latent factor is better explained by some other variables (from a different factor) than by its own observed variables (Hair et al., 2010).

Discriminant validity of the constructs was examined using the Fornell and Larcker (1981) test, namely that the square root of the average variance extracted for a given construct is greater than the standardized correlation of the given construct with each of the other constructs. As Table 2 shows, the Fornell and Larcker (1981) test is met for all pairs of constructs that are used in this study. All the constructs are noticeably different from each other.

Table 2. Discriminant Validity Matrix

\begin{tabular}{l|rrrrr}
\hline Construct & 1 & 2 & 3 & 4 & 5 \\
\hline 1. Brand Awareness & $\mathbf{. 9}$ & & & & \\
2. Corporate Image & .44 & $\mathbf{. 8 8}$ & & & \\
3.Purchase Intent & .47 & .45 & $\mathbf{. 8 1}$ &. $\mathbf{7 9}$ & \\
4.Loyalty & .34 & .44 & .39 & .44 & $\mathbf{. 8 3}$ \\
5.Team Attachment & .45 & .38 & .45 & .45
\end{tabular}

Convergent validity refers to a level of coherency across the items within each construct. First, convergence requires that the average variance extracted for each construct is greater than 0.50 (Fornell \& Larcker, 1981), which is met in the present study (refer to table 2). Secondly, all of the standardized factor loadings exceed .711 and are significant (p $<.001$ ), providing evidence of the convergent validity of the indicators (Anderson \& Gerbing, 1988). The goodness-of-fit index (GFI) and the adjusted goodness-of-fit index (AGFI) are 0.92 and 0.90, respectively. The chi-square statistic is $611(\mathrm{p}<0.001)$.

Reliability analysis was conducted on items of the questionnaire. We used Cronbach's alpha score to test the reliability of constructs. Cronbach's alpha is an index of reliability associated with the variation accounted for by the true score of the underlying construct (Hatcher, 1994). Cronbach's alpha is a measure of internal consistency that is, how closely related a set of items are as a group. Alpha coefficient ranges in value from zero to one and is used to describe the reliability of factors extracted from dichotomous and/or multi-point formatted questionnaires or scales. High values of Cronbach's alpha show the reliability of the generated scale. Nunnally (2010) has indicated Alpha with (.7) value to be an acceptable reliability coefficient. We used LISREL 8.52 to calculate alpha for each section separately. Table 3 shows each variable alpha related Cronbach's alpha. All values are greater than (.7) which indicates high reliability of items of the study.

Table 3. Cronbach's alpha and factor loadings of variables of the study and their related items

\begin{tabular}{l|c}
\hline Variables & Factor loading \\
\hline Brand Awareness $(\alpha=.94)$ & \\
$\mathrm{B}_{1}$ Brand Recall & .845 \\
$\mathrm{~B}_{2}$ Brand Recognition & .855 \\
Corporate Image $(\alpha=.85)$ & \\
$\mathrm{C}_{1}$ (positive attitude) & .798 \\
$\mathrm{C}_{2}$ (perception improvement) & .921 \\
$\mathrm{C}_{3}$ (product/service liking) & .879 \\
Purchase Intentions $(\alpha=.82)$ & \\
\hline
\end{tabular}




\begin{tabular}{l|r}
\hline $\mathrm{P}_{1}$ (considering buy in future) & .825 \\
$\mathrm{P}_{2}$ (will try to buy in future) & .711 \\
$\mathrm{P}_{3}$ (will purchase in future). & .922 \\
Loyalty $(\alpha=.79)$ & .859 \\
$\mathrm{~L}_{1}$ (recommendation of company products/services) & .841 \\
$\mathrm{~L}_{2}$ (regular use) & .911 \\
$\mathrm{~L}_{3}$ (repurchase) & .879 \\
Team Attachment $(\alpha=.83$ ) & .823 \\
$\mathrm{~T}_{1}$ (frequency of pursuing favourite team home games in stadium) & .901 \\
$\mathrm{~T}_{2}$ (frequency of pursuing favourite team away games in stadium) & \\
$\mathrm{T}_{3}$ (using sport kit of favourite team) & .
\end{tabular}

Five constructs comprise the final model and include brand awareness, corporate image, loyalty, purchase intention and team attachment. Confirmatory factor analysis shows that the measurement model works acceptably. The fit indices are greater than the 0.90 benchmark, with $\mathrm{GFI}=0.92$, AGFI $=0.93, \mathrm{CFI}=0.96$ and $\mathrm{NNFI}=0.90$. These indices indicate that the data fits the proposed model (Jöreskog, 1993). The levels of misfit were also tolerable, with RMSEA $=0.061$. The chi-square is 542 with 201 degrees of freedom statistically significant, which is not desirable, but it is common in samples with more than 300 . All the indices support construct validity of the model.

\section{Results}

The data were analyzed using structural equations modelling, employing path analysis with LISREL 8.52. Structural equation models (SEMs) explain relationships among variables. Structural equation model is similar to combining multiple regression and factor analysis. Structural Equation Modelling (SEM) has become one of the techniques of choice for researchers across different disciplines and increasingly is a 'must' for researchers and scholar in the social sciences (Hooper, Coughlan \& Mullen, 2008). In order to examine the hypotheses, we estimated the structural equation modeling, which proves the correlation between the constructs in a path diagram. The hypothesized structural model was tested by SEM, which included a test of the overall model as well as individual tests of the relationships among the latent constructs. The causal paths between the latent variables were specified in accordance with the Figure 1 and the model was tested using the maximum likelihood method of parameter estimation. We find strong support for drawing the conclusion that the model fits the data well. The chi-square statistic is 548 with 75 degrees of freedom $(p<0.001)$. The hypotheses test reveals that only brand awareness does not have a positive relationship with fan attachment. This implies that the team attachment does not influence the brand awareness. The path coefficient has the predictable direction, but the coefficient diverges only marginally from zero.

The results of the path analysis indicate that the model had a good fit with the data. The GFI is 0.91 and the AGFI is 0.92 while the CFI and NNFI are 0.95 and 0.89 respectively. RMSEA estimate is equal to 0.001 . The Goodness-of-Fit statistic (GFI) was created by Jöreskog and Sorbom as an alternative to the Chi-Square test and calculates the proportion of variance that is accounted for by the estimated population covariance (Tabachnick \& Fidell, 2007). AGFI tends to increase with sample size. As with the GFI's, values for the AGFI also range between 0 and 1 and it is generally accepted that values of 0.90 or greater indicate well-fitting models. In addition, the RMSEA shows us how well the model would fit the population's covariance matrix (Byrne, 1998). RMSEA values less than 0.05 indicate that a model has a close fit, values of .08 or less would indicate a reasonable fit, and RMSEA values higher than .10 should not be considered (Browne \& Cudeck, 1993).

Path diagram shows standardized coefficient estimates for the model using LISREL 8.52. All of the hypothesized paths are supported $(\mathrm{p}<.01)$ except path $1(\mathrm{H} 1)$. Significant path coefficients from team attachment to corporate image (.67), purchase intent (.69) and loyalty (.64) provided practical support for these hypotheses. The variance-covariance matrix of the observed variables (Brand Recall, Brand Recognition, Positive Attitude, Perception Improvement, Product/Service Liking, Considering Buy in Future, Will Try to Buy in Future, Will Purchase in Future, Recommendation of Company Products/Services, Regular Use, Repurchase, Frequency of Pursuing Favorite Team Home Games in Stadium, Frequency of Pursuing Favorite Team Away Games in a Stadium and Using Sport Kit of Favorite Team) was analyzed. The coefficients on the path between four main variables and team attachment are the standardized regression coefficients. Figure 2 shows the path analysis.

The path coefficients are unstandardized impacts. An impact score represents the effect of a change in the performance index of one point in latent variable. For instance, a 1-point increase in the performance index for team attachment directly results in a .67 increase in the corporate image index as shown in Figure 2. 


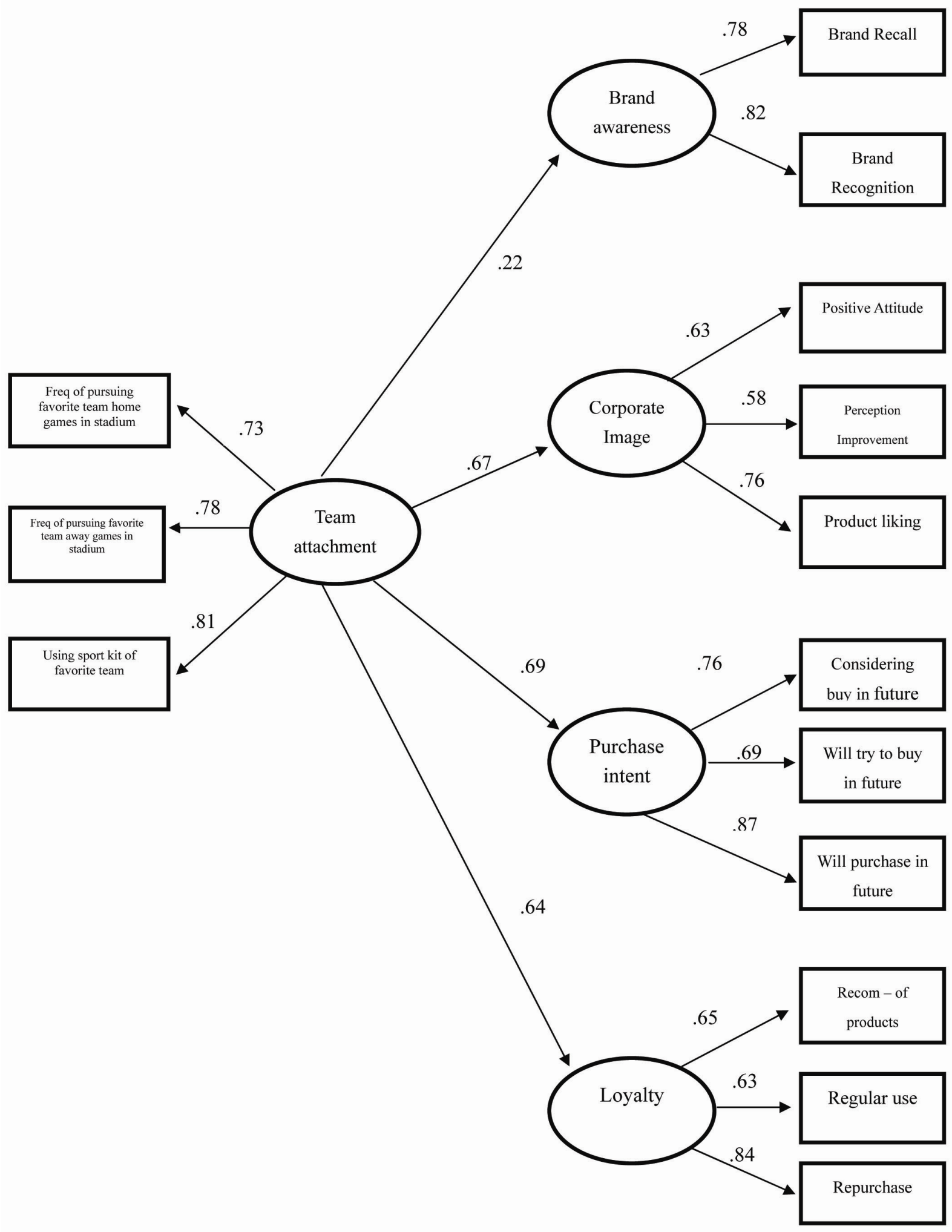

Figure 2. Path analysis of sport sponsorship effectiveness

Since no similar study has been conducted in Iran regarding soccer sponsorship effectiveness, we can compare the findings of this study with those of other studies in which the same kind of variables is used. According to results, 
soccer sponsorship through team attachment increases corporate image and purchase intention, and this is consistent with the findings of research that was conducted by Benekas (2007) who examined the soccer sponsorship effectiveness among Greek fans. In line with the study that was conducted by Schlesinger and Gungerich (2011) sport sponsorship through team attachment positively related to corporate image.

\section{Discussion}

The present study was conducted to test the effect of team attachment on sponsorship effectiveness and to develop a structural model for the causal relationships among them. The findings of this research are of interest to sponsorship researchers and professionals. Results of the structural equation analysis largely support the hypothesized relationships except H1. Hypotheses 2, 3 and 4 predicted that sport sponsorship through team attachment has a direct and positive influence on corporate image, purchase intentions and loyalty. Table 4 shows summary of hypotheses, conclusions and impacts. Purchase intent achieves the highest coefficient, .69, followed by corporate image (.67) and loyalty (.64).

Table 4. Path estimates for Structural model

\begin{tabular}{llc}
\hline Hypotheses & $\beta$ & Supported \\
\hline H1. Team attachment positively related to brand awareness & .22 & Not supported \\
H2.Team attachment positively related to corporate image & .67 & supported \\
H3.Team attachment positively related to Purchase intent & .69 & supported \\
H4.Team attachment positively related to Loyalty & .64 & supported \\
\hline
\end{tabular}

In the first hypothesis, it was proposed that sport sponsorship through team attachment did not increase brand awareness among soccer fans in Iran. For example, Marry Brown Fast Food restaurant, Iran Furniture Market and Iran Mobile Market spent millions of Dollars to sponsor Persepolis and Esteghlal teams, but among 384 respondents only seven people mentioned the names of these sponsors as the top of the mind sponsors. We could conclude that sport sponsorship cannot solely increase the brand awareness. Moreover, path analysis indicates that brand awareness has the lowest weight among sport sponsorship constructs. Therefore, corporations not only should sponsor the famous soccer clubs but also should coordinate all marketing activities in order to increase brand awareness among soccer fans.

The second research hypothesis proposes that team attachment through sport sponsorship has a positive impact on corporate image. Sport sponsorship enhances the corporate image of sponsors among soccer fans in Iran. The path analysis result also emphasizes that corporate image plays an important role in sport sponsorship effectiveness and has the highest weight among constructs. Through the sponsoring of soccer clubs, corporations create an image in the mind of fans that sponsors want to develop sports across the country and assist soccer clubs in their financial problems. It is recommended that corporations use sponsorship to improve the corporation image in society. In addition, sport sponsorship can increase the fame of the corporation and broadcast the record of the company.

The third research hypothesis predicts that team attachment through sport sponsorship increases purchase intention among soccer fans. According to the path analysis results, purchase intent affects sport sponsorship effectiveness. In Iran, many soccer clubs, especially private ones, are confronted with many financial problems, so they need a high volume of sponsorship contract to cover a portion of their expenses. Fans want to respond to sponsors' help by purchasing their products. We could conclude that sponsorship of soccer clubs especially popular ones can increase purchase intention and finally sales amounts.

The fourth research hypothesis is related to sport sponsorship's impact on loyalty. The results of the path analysis also indicate that sport sponsorship could increase fans' loyalty to sponsors. Liking of the favorite team and response to sponsors financial help are the two main reasons of increased loyalty. Sponsors should note that although sponsorship can lead to purchase of their products by soccer fans, the level of repurchase and loyalty could increase when they provide high quality products. Another point that sponsor should consider is their loyalty to soccer clubs. We observed that many sponsors simultaneously became sponsors of Persepolis and Esteghlal teams that are old rivals. Sometimes sponsors of one of these teams become the sponsor of the rival in next seasons. It does not have good reflection among soccer fans in Iran. Sponsors should continue their sponsorship for at least two consecutive seasons.

\section{Conclusion}

This paper has proposed a model for evaluating sponsorship effectiveness that researchers and practitioners can employ it. Although sponsorship activities have been popular and ubiquitous in most developed countries, sponsorship for Iranian companies and sports clubs is still a new phenomenon. In this study, the authors examined in 
some details the five currently most widely used metrics used in evaluating sponsorship effectiveness. From a practitioner perspective, organizations that are active in the sponsorship field such as ESA and IEG have sought to address some basic aspects of the evaluation issue such as media exposure and brand awareness. They argued for a changed perspective on measurement (ESA, 2009; IEG, 2012). Each country has its popular sports which attract different kinds of fans to the stadium and sports arena. Therefore, companies will choose a sport activity for sponsorship that is congruent and compatible with their target markets characteristics. According to the lack of appropriate secondary and archival data and difficulties in measuring the level of variables such as media exposure in Iran, the proposed model in this study will provide an appropriate platform for researchers and marketing managers to evaluate sport sponsorship effectiveness. Sponsorship as an emerging industry in Iran must be explored and investigated more deeply and new understandings of "how sponsorship works" is a must for growth of sponsorship industry in Iran. This model will give an opportunity to researchers and scholars to fill the void that exists in sponsorship industry in Iran.

\section{Limitations and Future Directions}

The research reported in this paper is subject to several limitations, which must be considered when interpreting the results. We electronically sent questionnaires to the respondents whose education levels were higher than the education levels of ordinary fans. The majority of Internet users in Iran have a high level of education. In addition, distribution of questionnaires in a stadium may lead to different results.

In this study, we only examine the sponsorship effects among Persepolis and Esteghlal fans. In future studies, we can investigate sport sponsorship effects on other soccer clubs' fans in Iran. Another interesting area for further study would be the spread of the scope of this research to other popular sports in Iran. In the present study, we investigate sport sponsorship from fans' perspective. We can evaluate sport sponsorship from an internal point of view. Another fruitful area of future empirical research might focus on examining the effects of sponsorship on amounts of sales and other financial indicators.

\section{References}

Aaker D.A. (1991). Managing brand equity. The Free Press, New York, NY.

Abratt, R. \& Grobler, P.S., (1989). The evaluation of sport sponsorship. International Journal of Advertising, 8(4), 351-362.

Alexandris, K., Tsaousi, E. \& James, J. (2007). Predicting sponsorship outcomes from attitudinal constructs: the case of a professional basketball event. Sport Marketing Quarterly, 16(3), 130-9.

Anderson, J.C. \& Gerbing, D.W. (1988). Structural equation modeling in practice: a review and recommended two-step approach. Psychological Bulletin, 103(3), 411-23. http://dx.doi.org/10.1037//0033-2909.103.3.411

Benekas, D. (2007). A critical evaluation of sport sponsorship and its effectiveness among football audiences in Greece. MA dissertation, University of Portsmouth.

Bennett, R. (1999). Sports sponsorship, spectator recall and false consensus. European Journal of Marketing, 33(3/4), 291-313. http://dx.doi.org/10.1108/03090569910253071

Bennett, G., Henson, R. \& Zhang, J. (2002). Action Sports Sponsorship Recognition. Sport Marketing Quarterly, 11 (3), 174-185.

Berrett, T. (1993). The sponsorship of amateur sport-government, national sport organization and the corporate perspectives. Leisure and Society, 16, 323-46.

Browne, M.W. \& Cudeck, R. (1993). Alternative ways of assessing model fit, in Bollen, A.K. and Long, J.S. (Eds.): Testing Structural Equation Models, 136-161, Sage, Newbury Park. http://dx.doi.org/10.1177/0049124192021002005

Byrne, B.M. (1998), Structural Equation Modeling with LISREL, PRELIS and SIMPLIS: Basic Concepts, Applications and Programming. Mahwah, New Jersey: Lawrence Erlbaum Associates.

Cornwell, T.B., Roy, D.P., \& Steinard, E.A. (2001). Exploring Manager's Perceptions of the Impact of Sponsorship on Brand Equity. Journal of Advertising, 30(2), 41-51. http://dx.doi.org/10.1080/00913367.2001.10673636

Cornwell, T.B. \& Maignan, I. (1998). An international review of sponsorship research. Journal of Advertising, 27(1), 1-21. http://dx.doi.org/10.1080/00913367.1998.10673539

Couty, F. (1994), L'évaluation de la notoriété du sponsoring sportif. Revue Française du Marketing, 150, 75-82. 
Crompton, J. L. (1994). Measuring the return on sponsorship investments at major recreation events. Journal of Park and Recreation Administration. 12(2), 73-85.

Crompton, J. L. (2004). Conceptualization and alternate operationalization of the measurement of sponsorship effectiveness in sport. Leisure Studies, 23(3), 267-281. http://dx.doi.org/10.1080/0261436042000183695

D’Astous, A., \& Bitz. P., (1995). Consumer evaluations of sponsorship programmes. European Journal of Marketing, 29(12), 6-22. http://dx.doi.org/10.1108/03090569510102504

Dees, W., Bennett, G., \& Villegas, J. (2008). Measuring the effectiveness of sponsorship of an elite intercollegiate football program. Sport Marketing Quarterly, 17(2), 79-89.

Deloitte, (2011). The untouchables football money league. Football Money League 2011 Sports Business Group. Manchester, UK.

Dichter, E. (1985). What's in an image?. Journal of Consumer Marketing, 2(1), 75-81. http://dx.doi.org/10.1108/eb038824

Easton, S. \& Mackie, P. (1998). When football came home: A case history of the sponsorship activity at EURO 96. International Journal of Advertising, 17(1). 99-114.

ESA, (2009). European Sponsorship Association, Sponsorship Assessment \& Evaluation Guidelines. London. Retrieved from: http://www.sponsorshipconsulting.co.uk/assets/presentations/ESA\%20Evaluation\%20Framework\%20Exec.\%20 Summ.pdf.

Faed, A., (2007). Strategic assessment of sport sponsorship as a marketing communication tool in electronic industries of Iran. Master thesis, Department of Marketing and E- Commerce, Tarbiat Modarres University, Tehran.

Fornell, C., \& Larcker, D. (1981). Evaluating structural equation models with unobservable variables and measurement error. Journal of Marketing Research, 18, 39-50 February. http://dx.doi.org/10.2307/3151312

Gatewood, R.D., Gowan, M.A. \& Lautenschlager, G.J. (1993). Corporate image, recruitment image, and initial job choice decisions. Academy of Management Journal, 35(2), 414-27. http://dx.doi.org/10.2307/256530

Gwinner, K. \& Swanson, S. (2003). A model of fan identification: antecedents and sponsorship outcomes. Journal of Services Marketing, 17(3), 275-94. http://dx.doi.org/10.1108/08876040310474828

Gwinner, K. (1994). Event Sponsorship as a Promotional Tool: the Impact of Brand Awareness and Brand Image. In Marketing Theory and Applications, 5, Proceedings of the 1994 AMA Winter Educators' Conference.

Hair, J., Black, W., Babin, B., \& Anderson, R. (2010). Multivariate data analysis (7th ed.): Prentice-Hall, Inc. Upper Saddle River, NJ, USA.

Hansen, F., \& Scotwin, L. (1995). An experimental enquiry into sponsoring: What effects can be measured?. Marketing and Research Today, 23(3), 173-181.

Harvey, B., Gray, S., \& Despain, G., (2006). Measuring the effectiveness of true sponsorship. Journal of Advertising Research, 46(4), 398-409. http://dx.doi.org/10.2501/S0021849906060478

Harvey, B. (2001). Measuring the effects of sponsorships. Journal of Advertising Research, 41(1), 59-64.

Hatcher, L. (1994). A step-by-step approach to using the SAS(R) system for factor analysis and structural equation modeling. Cary, NC: SAS Institute.

Hooper, D., Coughlan, J. \& Mullen, M. R. (2008). Structural Equation Modelling: Guidelines for Determining Model Fit. The Electronic Journal of Business Research Methods, 6 (1), 53 - 60.

IEG., (2013). A sponsorship measurement solution: Applying marketing science to evaluating performance. IEG Report.

Retrieved

from: http://www.sponsorship.com/IEG/files/07/07903e35-98d1-4f1c-b318-7524b3104222.pdf.

IEG, (2011). Sponsorship spending report. IEG Sponsorship Report, Retrieved from: http://www.sponsorship.com/IEG/files/fc/fcbe683b-d2a8-4f0b-9b35 121a86ab3a2b.pdf

Izadi, A. (2004). Description of effective factors in attracting sponsors for Iran pro-league. Sports science and education Master dissertation, Tarbiat Moalem University, Tehran.

Ja valgi, R.G., Traylor, M.B., Gross, A.C. \& Lampman, E. (1994). Awareness of sponsorship and corporate image: 
and empirical investigation. Journal of Advertising, 23(4), 47-58.

Jensen, J. M., \& Hansen, T. (2006). An empirical examination of brand loyalty. Journal of product and brand management. 15(7), 442-449. http://dx.doi.org/10.1108/10610420610712829

Jöreskog, K. G. (1993). Testing structural equation models. Sage focus editions, 154, 294-294.

Keller , K.L. (1993). Conceptualizing, measuring and managing customer-based brand equity. Journal of Marketing, 57(1), 1-22. http://dx.doi.org/10.2307/1252054

Kim, J. (2010). The worth of sport event sponsorship: an event study. Journal of Management and Marketing Research, 5(1). 1-14.

Ko, Y.J., Kim, K., Claussen, C.L \& Kim, T.H (2008). The effects of sport involvement, sponsor awareness and corporate image on intention to purchase sponsors' products. International Journal of Sports Marketing \& Sponsorship, 9(2), 79-94.

Koo, K., Quarterman, J., \& Flynn, L., (2006). Effect of perceived sport event and sponsor image fit on consumers' cognition, affect, and behavioral intentions. Sport Marketing Quarterly, 15(2), 80-90.

Lardinoit, T. \& Derbaix, C. (2001). Sponsorship and recall of sponsors. Psychology \& Marketing, 18(2), 167-190. http://dx.doi.org/10.1002/1520-6793(200102)18:2<167::AID-MAR1004>3.3.CO;2-9

Lawshe, C. H. (1975). A quantitative approach to content validity. Personnel Psychology. 28(4), 563-575. http://dx.doi.org/10.1111/j.1744-6570.1975.tb01393.x

Mason, R.B. \& Cochetel, F., (2006). Residual brand Awareness following the termination of a long-term event sponsorship and the appointment of a new sponsor. Journal of Marketing Communications, 12(2), 125-144. http://dx.doi.org/10.1080/13527260600630450

McDaniel, S.R. (1999). An investigation of match-up effects in sport sponsorship advertising. Psychology \& Marketing, $16(2)$,

$163-184$. http://dx.doi.org/10.1002/(SICI)1520-6793(199903)16:2<163::AID-MAR6>3.0.CO;2-Y

Meenaghan, T., \& O'Sullivan, P. (2013). Metrics in sponsorship research - is credibility an issue?. Psychology \& Marketing, 30(5), 408-416. http://dx.doi.org/10.1002/mar.20615

Meenaghan, T., (2001). Understanding sponsorship effects. Psychology and Marketing, 18(2), 95-122. http://dx.doi.org/10.1002/1520-6793(200102)18:2<95::AID-MAR1001>3.3.CO;2-8

Meenaghan, T. \& Shipley, D., (1999). Media effect in commercial sponsorship. European Journal of Marketing, 33(3/4), 328-347. http://dx.doi.org/10.1108/03090569910253170

Meenaghan, T. (1996). Ambush Marketing - A Threat to Corporate Sponsorship. Sloan Management Review, 38(1), 103-113.

Meenaghan, T. (1983). Commercial sponsorship. European Journal of Marketing, 17(7), 5-73. http://dx.doi.org/10.1108/EUM0000000004825

Miloch, K.S. \& Lambert, K.W., (2006). Consumer awareness of sponsorship at grassroots sport events. Sport Marketing Quarterly, 15(3), 147-154

Mohammad Kazemi, R. (2007). Description of marketing mixes in Iran football industry and its comparison with Japan and Korea pro-leagues. Sport Science and Education Doctoral dissertation, Tarbiat Moalem University, Tehran.

Müller, F., (1983). Banden und sportwerbung eine untersuchung zur wirkung von bandenwerbung und zur einstellung gegenüber werbung im sport. Interview und Analyse, 10(4/5), 152-156.

Nicholls, J.A.F, Roslow, S., \& Laskey, H.A., (1994). Sports event sponsorship for brand promotion. Journal of Applied Business Research, 10(2), 35-40.

Nunnally, J. C. (2010). Psychometric Theory 3E. Tata McGraw-Hill Education.

O’Reilly, N., \& Madill, J. (2009). Methods and Metrics in sponsorship evaluation. Journal of Sponsorship, 2(3), 215-230.

Olson, E. \& Thjomoe, H.M., (2009). Sponsorship effect metric: assessing the financial value of sponsoring by comparisons to television advertising. Journal of Academy of Marketing Sci., 37(4), 504-515. http://dx.doi.org/10.1007/s11747-009-0147-z 
Persian Gulf Professional Football League, (2011). Retrieved August 13, 2011 from http://www.pgfleague.ir

Pope, N., \& Voges, K.E., (1999). Sponsorship and image: a replication and extension. Journal of Marketing Communication, 5(1), 17-28. http://dx.doi.org/10.1080/135272699345716

Pope, N. (1998). Overview of current sponsorship thought. The Cyber-Journal of Sport Marketing, 2(1), http://www.cjsm.com/vol2/pope21.htm.

Quester, P.G. \& Farrelly, F., (1998). Sports and arts sponsors: Investigating the similarities and differences in management practices. Proceedings of the American Marketing Association Conference, Dublin, 874-86.

Rajaretnam, J. (1994). The long-term effects of sponsorship on corporate and product image: findings of a unique experiment. Marketing and Research Today, February, 62-74.

Sandler, D.M. \& Shani, D. (1989). Olympic sponsorship vs. ambush marketing: who gets the gold?. Journal of Advertising Research, 29(4), 9-14.

Schlesinger, T. \& Güngerich, M. (2011). Analyzing sport sponsorship effectiveness - the influence of fan identification, credibility and product-involvement. Int. J. Sport Management and Marketing, 9(1/2), 54-74. http://dx.doi.org/10.1504/IJSMM.2011.040257

Simmons, C. J., \& Becker-Olsen, K. L. (2006). Achieving marketing objectives through social sponsorships. Journal of Marketing, 70, 154-169. http://dx.doi.org/10.1509/jmkg.70.4.154

Smith, A., (2008). Introduction to sport marketing. Elsevier Ltd. http://dx.doi.org/10.1016/B978-0-7506-8685-3.50004-2

Speed, R. \& Thompson, P., (2000). Determinants of Sports Sponsorship Response. Journal of the Academy of Marketing Science, 28(2), 226-238. http://dx.doi.org/10.1177/0092070300282004

Tabachnick, B.G. \& Fidell, L.S. (2007). Using Multivariate Statistics (5th ed.). New York: Allyn and Bacon.

Tsiotsou, R., \& Alexandris, K., (2009). Delineating the outcome of sponsorship. International Journal of Retail and Distribution Management, 37(4), 358-369. http://dx.doi.org/10.1108/09590550910948583

Turco, D.M. (1995). The effects of sport sponsorship on product recall and corporate image. In K. Grant and I. Walker (eds) World Marketing Congress. Melbourne: Academy of Marketing Science, 11.6-11.10.

Vignali, C., (1997). The MIXMAP - model for international sport sponsorship. European Business Review, 97(4), 187-193. http://dx.doi.org/10.1108/09555349710175315

Wann, D.L. \& Branscombe, N.R. (1993). Sports fans: measuring the degree of identification with their team. International Journal of Sport Psychology, 24, 1-17. 